Global Conferences Series:

Sciences and Technology (GCSST), Volume,5, 2020

Seminar Nasional I Baristand Industri Padang (Semnas I BIPD)

DOI:https://doi.org/10.32698/GCS-SNIIBIP D3436

\title{
The effect of hydro electric power plant on the water quality of the Brantas River
}

\section{Pengaruh kegiatan pembangki listrik tenaga air terhadap kualitas air Sungai Brantas}

\author{
Liayati Mahmudah ${ }^{1}$, Ardhaningtyas Riza Utami ${ }^{1}$ \\ Balai Riset dan Standardisasi Industri Surabaya, Indonesia \\ E-mail: lia.mahmudah@yahoo.com
}

\begin{abstract}
The Brantas Generating Unit operates 13 Hydro Power Plants (PLTA) along the Konto River and the Brantas River. This study aims to see the effect and impact of the hydroelectric power generation unit on river quality in terms of Biological Oxygen Demand (BOD), oil and fat, and phenol levels. Sampling was carried out at the intakes and outlets of 10 hydroelectric power generation units along the Brantas River. From the research results obtained that the levels of BOD, oil and fat, and phenol levels have decreased in most of the hydroelectric power generation units in the Brantas River in East Java. The average reduction in BOD content was about $50 \%$, the average reduction in oil and grease content was around $29 \%$, and the average decrease in phenol content was around 44\%. From the data obtained, it can be concluded that the existence of a hydroelectric power generation unit has a positive impact on the quality of river water used.
\end{abstract}

Keywords: Biological Oxygen Demand (BOD); oil and grease; phenol; Brantas River

\begin{abstract}
Abstrak: Unit Pembangkitan Brantas mengoperasikan 13 Pembangkit Listrik Tenaga Air (PLTA) di sepanjang Kali Konto dan Kali Brantas. Penelitian ini bertujuan untuk melihat pengaruh dan dampak adanya unit pembangkitan listrik tenaga air terhadap kualitas sungai dari segi kadar Biological Oxygen Demand (BOD), minyak dan lemak, dan kadar fenol. Pengambilan sampel dilakukan di intake dan outlet 10 unit pembangkitan listrik tenaga air di sepanjang aliran Sungai Brantas. Dari hasil penelitian diperoleh data bahwa kadar BOD, minyak dan lemak, dan kadar fenol mengalami penurunan di hampir sebagian besar unit pembangkitan listrik tenaga air yang ada di aliran Sungai Brantas wilayah Jawa Timur. Rata-rata penurunan kadar BOD sekitar $50 \%$, rata-rata penurunan kadar minyak dan lemak sekitar $29 \%$, dan rata-rata penurunan kadar fenol sekitar 44\%. Dari data yang diperoleh dapat disimpulkan bahwa keberadaan unit pembangkitan listrik tenaga air memberikan dampak positif terhadap kualitas air sungai yang digunakan.
\end{abstract}

Kata kunci: Biological Oxygen Demand (BOD); minyak dan lemak; fenol; Sungai Brantas

\section{PENDAHULUAN}

Jawa Timur memiliki aliran sungai cukup deras di sepanjang wilayah Jawa Timur. Dua sungai besar yang melintasi wiayah Jawa Timur, yaitu Sungai Brantas dan Sungai Bengawan Solo yang membelah wilayah Jawa Timur. Kali Brantas (sekitar $320 \mathrm{~km}$ ) adalah sebuah sungai di Jawa Timur yang merupakan sungai terpanjang kedua di Pulau Jawa setelah Bengawan Solo. DAS Kali Brantas seluas $11.988 \mathrm{~km} 2$, terdiri dari 6 Sub DAS, 32 Basin Block. Sepanjang wilayah selatan Jawa Timur dilintasi oleh sungai berantas yang memiliki aliran cukup deras, karena wilayah Jawa Timur bagian selatan memiliki gunung berapi yang cukup banyak, sehingga menjadikan topografi wilayah Jawa Timur memiliki banyak wilayah perbukitan. Sungai dengan aliran yang deras ini merupakan salah satu sumber daya alam yang sangat berpotensial dimanfaatkan menjadi sumber listrik yang dapat digunakan oleh seluruh masyarakat Jawa Timur dan sekitarnya.

Kali Brantas bermata air di Desa Sumber Brantas (Kota Batu), lalu mengalir ke Malang, Blitar, Tulungagung, Kediri, Jombang, Mojokerto. Di Kabupaten Mojokerto sungai ini bercabang dua manjadi Kali

Copyright (C) 2020, the Authors. Published by Redwhite Press. 
Mas (ke arah Surabaya) dan Kali Porong (ke arah Porong, Kabupaten Sidoarjo). (Balai Besar Teknologi Modifikasi Cuaca, 2016).

Pembangkit Listrik Tenaga Air (PLTA) adalah suatu pembangkit listrik dengan media kerja air. Secara umum, PLTA adalah mesin konversi energi yang terdiri dari dam (bendungan), reservoir, penstock (pipa pesat), turbin, draft tube, power house dan electricity terminal seperti dalam Gambar 1. Dalam suatu sistem PLTA (Pembangkit Listrik Tenaga Air), turbin merupakan suatu peralatan utama selain generator. Sistem kerjanya adalah dengan memanfaatkan arus aliran air dari sungai yang kemudian di tampung pada sebuah dam (bendungan) yang kemudian dialirkan pada suatu rangkaian pipa agar energi potensial air dapat diubah menjadi energi kinetik, sehingga pada akhirnya diubah kembali menjadi energi mekanis untuk menggerakkan atau memutarkan turbin. Hal tersebut menyebabkan generator yang seporos dengan turbin dapat berputar, maka dengan proses yang terjadi tersebut induksi elektromagnetik yang menghasilkan energi listrik (Hidayat, 2019).

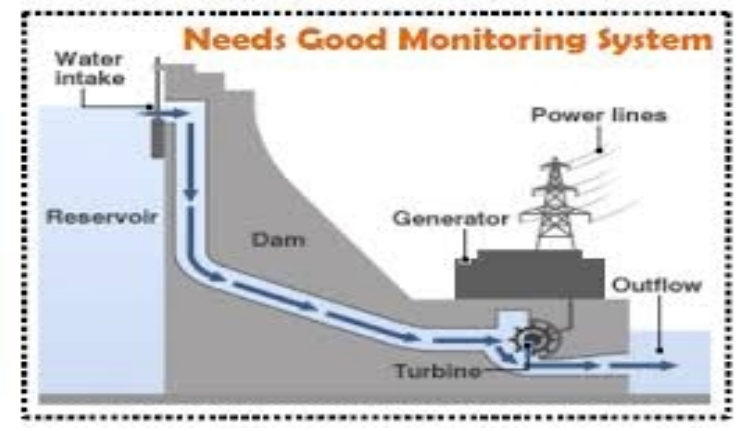

Gambar 1. Proses Kerja PLTA

Unit Pembangkitan brantas merupakan salah satu Unit Pembangkit listrik yang ada di wilayah Jawa Timur dengan memanfaatkan sepanjang aliran Sungai Brantas. Unit Pembangkitan Brantas memiliki 13 unit PLTA yang tersebar di 5 kabupaten. Unit PLTA dibawah UP Brantas antara lain PLTA Senguruh, Sutami, Wlingi, Lodoyo, Tulungagung, Selorejo, Mendalan, Siman, Giringan, Golang, Ngebel, dan Wonorejo (PT PJB, 2020).

Novia Lusiana melakukan riset terkait prediksi distribusi pencemaran air Sungai Brantas hulu kota batu pada musim hujan dan kemarau. Sebaran kadar BOD pada Sungai Brantas pada musim hujan menunjukkan semakin ke daerah hilir nilai BOD semakin tinggi dengan rentang nilai BOD sebesar 2.6 - 18.7 $\mathrm{mg} / \mathrm{L}$, sedangkan pada musim kemarau rentang nilai BOD $5.63-9.95 \mathrm{mg} / \mathrm{L}$. Nilai COD pada musim hujan menunjukkan sebaran semakin ke hilir cenderung semakin meningkat dengan rentang nilai lebih tinggi dibandingkan pada musim kemarau dengan nilai $6.53-61.24 \mathrm{mg} / \mathrm{L}$. Pada musim kemarau menunjukkan nilai rentang lebih rendah sebesar 17.52 - $26.3 \mathrm{mg} / \mathrm{L}$ dengan kecenderungan semakin ke hilir mengalami peningkatan. .Zona degradasi Sungai Brantas Hulu Kota Batu pada jarak $2 \mathrm{~km}$ sudah mengalami penurunan DO pada musim hujan dan kemarau (Lusiana et al., 2018).

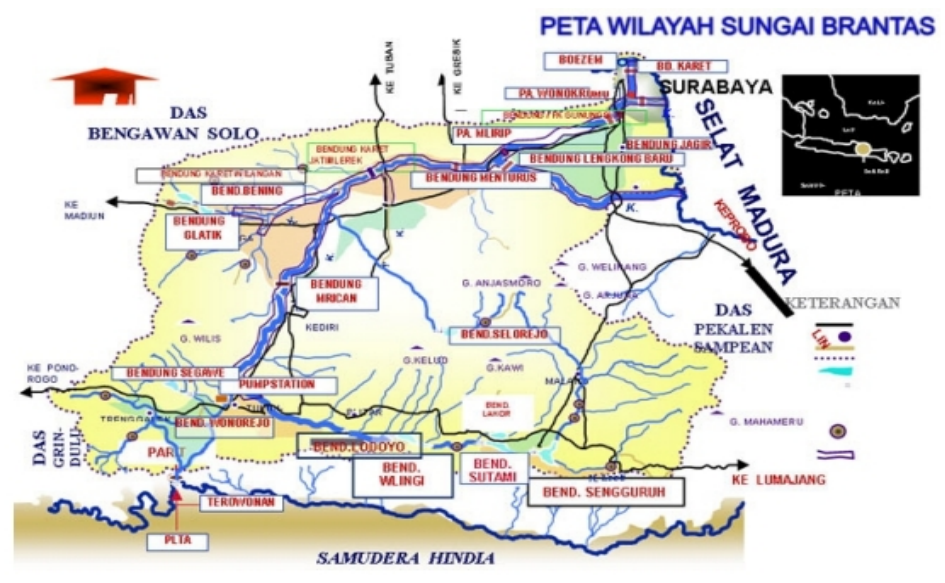

Gambar 2. Peta Wilayah Sungai Brantas 
Elvi Yett menyatakan dalam jurnalnya bahwa sebagian besar sungai-sungai di kawasaan DAS Brantas Hulu Malang tidak lagi memiliki kualitas air yang layak untuk peruntukan perikanan dan pertanian, baik menurut Keputusan Gubernur Jatim No. 413 tahun 1987 maupun Peraturan Pemerintah No. 82 tahun 2001. Kualitas air sungai di kawasan DAS Brantas Hulu Malang telah mengalami penurunan terutama disebabkan oleh sampah organik (Yetti, Soedharma and Haryadi, 2011).

Penelitian mengenai dampak pembangunan PLTA dari segi sosial ekonomi telah dilakukan oleh Olvit Olniwati Kayupa pada tahun 2015, dimana dampak sosial dan ekonomi yang timbul dari pembangunan PLTA Sulewana adalah tingkat sosial dan ekonomi meningkat cukup signifikan yaitu sebesar 79,30\% terlihat dari tingkat pendidikan, kesehatan, bahkan pendapatan yang membaik pada masyarakat di Desa Sulewana (Kayupa, 2015). Sedangkan dalam penelitian ini bertujuan untuk melihat dampak pembangunan PLTA terhadap kualitas air sungai.

Sumber kontaminan/pencemar dari kegiatan PLTA antara lain sisa oli/pelumas yang digunakan untuk motor turbin, pompa, dan lain-lain. Turbulensi dari kincir menyebabkan bahan suspensi yang ada di perairan meningkat. Oleh karena itu parameter yang dipilih adalah BOD, minyak lemak dan fenol. Dalam penelitian ini dilakukan riset untuk mengetahui pengaruh pembangunan Unit Pembangkitan Listrik Tenaga Air terhadap kualitas air sungai di sepanjang aliran Sungai Brantas, dilihat dari parameter BOD, minyak lemak, dan fenol.

\section{METODE}

\section{Pengambilan Sampel}

Pengambilan sampel air sungai dilakukan di beberapa PLTA wilayah Sungai Brantas di wilayah jawa timur, antara lain PLTA selorejo, Wlingi, Lodoyo, Wonorejo, Tulungagung, Ngebel, Golang, Ampel Gading, Sengguruh dan Sutami. Karena Pembangkit bekerja secara kontinu, maka sampel diambil 1 kali pada bulan Januari 2019 pada bagian intake dan outlet dari PLTA untuk mengetahui perbedaan kadar BOD, Minyak dan Lemak, serta Fenol.

\section{Metode Pengujian}

Kualitas air sungai dalam penelitian ini yang dilihat adalah kadar BOD, Minyak Lemak dan fenol. Analisa BOD dilakukan sesuai SNI 6989.72 : 2009, analisa Minyak dan Lemak sesuai SNI 6989.10:2011, pengujian fenol menggunakan SNI 06-6989.21.2004.

\section{Baku Mutu}

Baku Mutu yang digunakan berdasarkan Peraturan Pemerintah No. 82 tahun 2001. Parameter uji dalam penelitian dibatasi untuk parameter BOD, Minyak Lemak dan Fenol (Kementerian Lingkungan Hidup, 2001).

Tabel 1 Kriteria Mutu Air Berdasarkan Kelas.

\begin{tabular}{lllll}
\hline Parameter & \multicolumn{3}{c}{ Kelas } \\
& I & II & III & IV \\
\hline BOD $(\mathrm{mg} / \mathrm{L})$ & 2 & 3 & 6 & 12 \\
Minyak dan Lemak $(\mu \mathrm{g} / \mathrm{L})$ & 1000 & 1000 & 1000 & - \\
Fenol $(\mathrm{mg} / \mathrm{L})$ & 1 & 1 & 1 & - \\
\hline
\end{tabular}

*Lampiran PP No. 82 Tahun 2001

\section{HASIL DAN PEMBAHASAN}

Pada Tabel 2 merupakan hasil pengujian kadar BOD, Minyak dan Lemak, serta Fenol untuk sampel intake dan outlet dari Unit Pembangkitan Listrik Tenaga Air yang terletak di aliran Sungai Brantas. Kadar Minyak dan Lemak serta fenol diatas baku mutu kualitas air kelas III, dimana syarat mutu minyak lemak adalah $1000(\mu \mathrm{g} / \mathrm{L})$ dan fenol adalah $1 \mathrm{mg} / \mathrm{L}$. Dari table 2. Ini juga dapat dilihat perubahan konsentrasi kadar BOD, Minyak dan Lemak serta fenol antara intake maupun outlet dari Unit Pembangkit Listrik. Rata - rata penurunan kadar BOD sekitar 50\%, rata - rata penurunan kadar minyak dan lemak sekitar 29\%, dan rata rata penurunan kadar fenol sekitar 44\%. Untuk mengetahui tren dari perubahan konsentrasi masing - masing parameter dari intake maupun outlet maka dibuat perbandingan melalui kurva.

Pada Gambar 3 menunjukkan tren perubahan kadar BOD antara intake dan outlet dari unit PLTA. 6 dari 10 PLTA menunjukkan penurunan kadar Biological Oxygen Demand (BOD) setelah melewati proses 


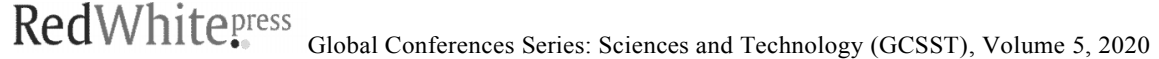

unit pembangkitan listrik. Hal ini disebabkan karena adanya perputaran turbin pada unit pembangkitan listrik, sehingga aliran menjadi turbulen dan bisa menjadi proses aerasi di perairan. Di dalam perairan sudah ada bakteri pengurai yang hidup, yang mampu mendegradasi limbah yang ada dalam perairan (Prasetyo dan Fidiastuti, 2015). Dengan adanya aerasi secara tidak langsung yang berasal dari gerkan turbin, dapat berfungsi menambahkan suplai oksigen untuk bakteri yang ada diperairan yang berperan dalam penguraian bahan organik, penambahan oksigen ini untuk memaksimalkan oksidasi bahan organic secara biologi oleh mikroba, reaksi oksidasi ini menghasilkan $\mathrm{CO}_{2}, \mathrm{NH}_{3}, \mathrm{H}_{2} \mathrm{O}$ dan sludge. Sludge ini merupakan sel sel baru dari mikroba, yang disebut sebagai activated sludge. Activated sludge ini berfungsi untuk menguraikan kandungan bahan organik, sehingga kadar BOD menurun (Edahwati and Suprihatin, 2012).

Tabel 2. Hasil Pengujian

\begin{tabular}{|c|c|c|c|c|}
\hline \multirow[t]{2}{*}{ Unit PLTA } & & \multicolumn{3}{|c|}{ Parameter } \\
\hline & & BOD $(\mathrm{mg} / \mathrm{L})$ & Minyak Lemak $(\mu \mathrm{g} / \mathrm{L})$ & Fenol (mg/L) \\
\hline \multicolumn{2}{|c|}{ Syarat Mutu Air kelas II } & 3 & 1000 & 1 \\
\hline \multirow[t]{2}{*}{ Selorejo } & Intake & 4,1 & 3950 & 75 \\
\hline & Outlet & 5,82 & 2390 & 0 \\
\hline \multirow[t]{2}{*}{ Wlingi } & Intake & 6,17 & 2580 & 213 \\
\hline & Outlet & 4,05 & 1970 & 0 \\
\hline \multirow[t]{2}{*}{ Lodoyo } & Intake & 3,1 & 2190 & 180 \\
\hline & Outlet & 4,85 & 1000 & 295 \\
\hline \multirow{2}{*}{ Wonorejo } & Intake & 3,42 & 2780 & 195 \\
\hline & Outlet & 2,53 & 2370 & 129 \\
\hline \multirow{2}{*}{ Tulungagung } & Intake & 7,29 & 2960 & 359 \\
\hline & Outlet & 4,26 & 1780 & 243 \\
\hline \multirow[t]{2}{*}{ Ngebel } & Intake & 2,98 & 1990 & 341 \\
\hline & Outlet & 1,16 & 2790 & 287 \\
\hline \multirow{2}{*}{ Golang } & Intake & 1,06 & 1780 & 296 \\
\hline & Outlet & 1,71 & 1000 & 278 \\
\hline \multirow[t]{2}{*}{ Ampel Gading } & Intake & 5,13 & 1770 & 326 \\
\hline & Outlet & 5,3 & 1370 & 360 \\
\hline \multirow[t]{2}{*}{ Sengguruh } & Intake & 5,3 & 3340 & 78 \\
\hline & Outlet & 1,79 & 2590 & 45 \\
\hline \multirow[t]{2}{*}{ Sutami } & Intake & 17,8 & 2170 & 63 \\
\hline & Outlet & 4,84 & 2160 & 51 \\
\hline
\end{tabular}

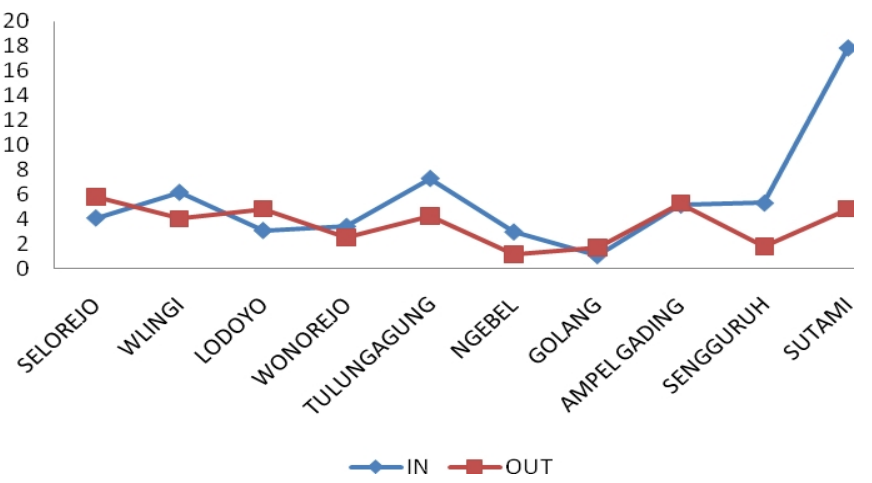

Gambar 3. Kadar BOD intake dan outlet PLTA

Sumber minyak dan lemak di perairan diduga berasal dari kegiatan rumah tangga, bengkel, restauran, dan sebagainya. Kandungan minyak dan lemak yang berlebih di perairan akan mengurangi penetrasi cahaya dan oksigen ke dalam air sehingga menghambat laju fotosintesis dan respirasi biota air, sehingga ekosistem perairan akan terganggu (Hendrawan, 2008). 


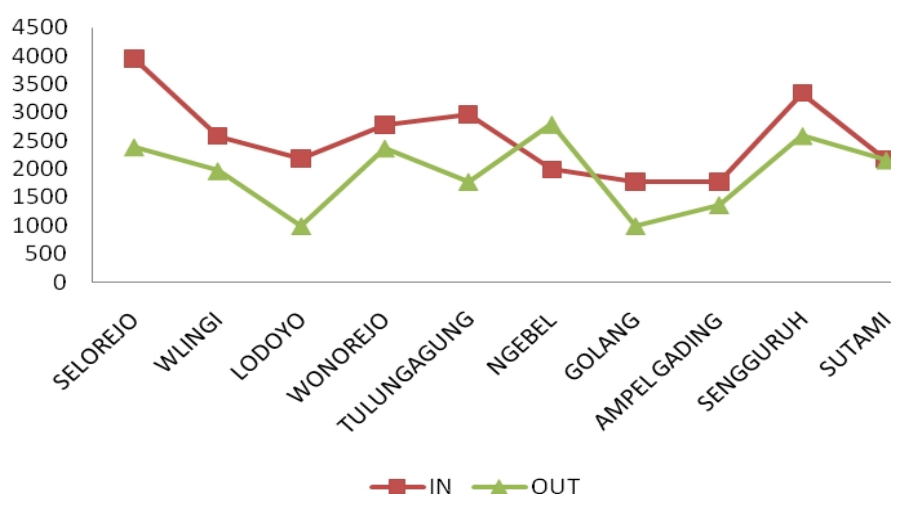

Gambar 4. Kadar Minyak dan Lemak intake dan outlet PLTA

Gambar 4 menunjukkan perubahan kadar minyak dan lemak dari aliran intake dan outlet beberapa unit pembangkitan listrik tenaga air. 9 dari 10 unit pembangkitan listrik menunjukkan kadar minyak dan lemak dari outlet mengalamai penurunan dibandingkan dengan pada bagian intake. Hal ini tidak sesuai dengan hipotesis awal bahwa kadar minyak lemak pada outlet akan meningkat karena adanya penambahan kadar minyak dari pelumas/oli turbin. Adanya gerakan dari turbin menyebabkan aliran turbulen dan secara tidak langsung menyebabkan oksigen masuk ke dalam perairan, sehingga secara tidak langsung kandungan minyak dan lemak terflotasi. Perlakuan aerasi dapat menurunkan kandungan minyak pada air limbah dan dapat memisahkan minyak yang terakumulasi di dalam air sehingga minyak dapat terdispersi ke atas (Maharani, 2017).

Fenol $\left(\mathrm{C}_{6} \mathrm{H}_{5}-\mathrm{OH}\right)$ merupakan monohidroksida turunan benzen dan bersifat anionik di dalam larutan air. Keberadaan fenol dalam air dapat menyebabkan pencemaran, karena jika dikonsumsi fenol dapat terakumulasi di dalam tubuh dan bersifat racun. Gambar 5 di bawah ini menunjukkan perubahan kadar fenol pada air sungai dari aliran intake dan outlet unit pembangkitan. 8 dari 10 unit pembangkitan listrik yang diambil sampel, menunjukkan penurunan kadar fenol air sungai setelah melewati unit pembangkitan listrik.

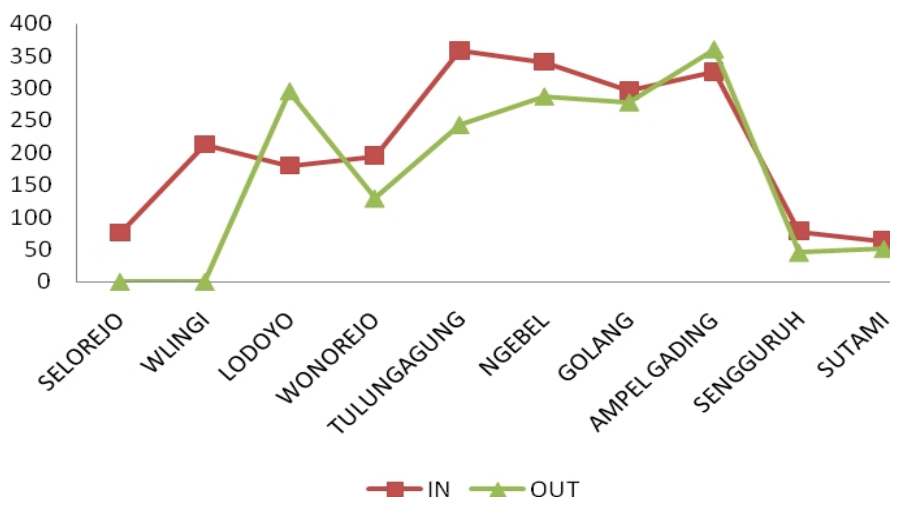

Gambar 5. Kadar Fenol intake dan outlet PLTA

Dari ketiga gambar di atas, diperoleh bahwa dengan adanya unit pembangkitan listrik tenaga air memberikan dampak positif terhadap kualitas air sungai. Hal ini dilihat dari penurunan kadar BOD, minyak dan lemak, fenol sebagian besar unit pembangkitan listrik tenaga air yang ada di aliran Sungai Brantas, meskipun penurunanya tidak terlalu signifikan namun setidaknya adanya unit pembangkitan listrik tenaga air ini, tidak menjadi sumber pencemar terhadap kualitas air sungai. Adanya proses mekanis dari unit pembangkitan listrik tenaga air, menjadikan aliran sungai menjadi turbulen, sehingga membantu oksigen terikat ke dalam air sungai, dan menyebabkan pertumbuhan mikroorganisme dalam air meningkat, yang mampu menurunkan kadar BOD, minyak dan lemak, maupun fenol.

Hal ini sesuai dengan penelitian yang dilakukan oleh Arsawan et al., (2007) dimana perlakuan aerasi juga dapat menurunkan nilai BOD, COD, TDS dan TSS karena dengan pemberian oksigen kedalam air limbah akan dapat memenuhi kebutuhan oksigen oleh mikroorganisme pengurai yang ada di dalam air limbah dan kebutuhan oksigen untuk oksidasi bahan-bahan kimia yang ada di dalam air limbah. Jadi perlakuan aerasi dapat meningkatkan kualitas limbah kearah yang lebih baik (Arsawan, et al., 2007). 


\section{SIMPULAN}

Dari penelitian dan analisa data yang dilakukan, dapat diperoleh kesimpulan bahwa adanya pembangunan Pembangkit Listrik Tenaga Air di sepanjang aliran Sungai Brantas, tidak menjadi beban pencemar baru terhadap kualitas perairan. Hal ini dilihat dari adanya penurunan konsentrasi BOD, Minyak dan Lemak, serta Fenol pada outlet Unit PLTA dibandingkan dengan konsentrasi pada titik intake.

\section{UCAPAN TERIMA KASIH}

Kami mengucapkan terima kasih kepada Balai Riset dan Standardisasi Industri Surabaya untuk dukungan fasilitas Laboratorium Lingkungan sebagai tempat riset dan pengujian sampel.

\section{REFERENSI}

Arsawan, M. Suyasa, I. W. B., Suama, W., 2007. Pemanfaatan metode aerasi dalam pengolahan limbah berminyak. Ecotrophic, 2(2), pp 1-9.

Balai Besar Modifikasi Cuaca, 2016. Monitoring TRMM untuk TMC DAS Brantas. Diakses http://wxmod.bppt.go.id/index.php/monitoring/image-satelit-gms/48-riset/ 235-monitoring-trmm-tmcdas-brantas.

Prasetiyo, N. A., Fidiastuti, H. R., 2015. Kajian pengaruh kecepatan aerasi dan waktu inkubasi terhadap kemampuan konsorsia bakteri indigendalam mendegradasi limbah cair kulit di industri penyamakan kulit kota malang. Saintifika, 17(1), $29-37$.

Edahwati, L. Suprihatin, 2012. Kombinasi proses aerasi, adsorpsi, dan filtrasi pada pengolahan air limbah industri perikanan, Jurnal Ilmiah Teknik Lingkungan, 1(2), pp. 79-83.

Hendrawan, D., 2008. Kualitas air Sungai Ciliwung ditinjau dari parameter minyak dan lemak. Ilmu - Ilmu Perairan dan Perikanan Indonesia, Desember(15), pp. 85-93.

Maharani, V. S., 2017. Studi Literatur : Pengolahan Minyak dan Lemak Limbah Industri. Tugas Akhir, Institut Teknologi Sepuluh Nopember.

Hidayat, W., 2019. Prinsip kerja dan komponen - komponen Pembangkit Listrik Tenaga Air (PLTA). doi: 10.31227/osf.io/drv58.

Kayupa, O. O., 2015. Dampak sebelum dan sesudah pembangunan pembangkit listrik tenaga air (PLTA) terhadap kondisi sosial dan ekonomi masyarakat di desa sulewana kecamatan, Jurnal Katalogis, 3(11), pp. 217-227.

Kementerian Lingkungan Hidup, 2001. PP No. 82 Tahun 2001 pengelolaan kualitas air dan pengendalian pencemaran air.

Lusiana, N. et al., 2018. Prediksi distribusi pencemaran air Sungai Brantas hulu kota batu pada musim hujan dan kemarau menggunakan metode spasial inverse, Ecotrophic, 12(2), pp. 211-224.

PT PJB., 2020. PT PJB Unit Pembangkitan Brantas. Diakses : http://www.upbrs.com/portal/index.php .

Yetti, E., Soedharma, D. Haryadi, S., 2011. Evaluasi kualitas air sungai-sungai di kawasan das brantas hulu malang dalam kaitannya dengan tata guna lahan dan aktivitas masyarakat di sekitarnya. JPSL, 1(1), pp. 10-15.

BSN, 2009. Standar Nasional Indonesia SNI 6989.72 : 2009, Air dan air limbah - bagian 72 : Cara uji kebutuhan oksigen biokimia (Biochemical Oxygen Demand/BOD). Badan Standardisasi Nasional.

BSN, 2011. Standar Nasional Indonesia SNI 6989.10:2011, Air dan air limbah - bagian 10 : Cara uji minyak nabati dan minyak mineral secara gravimetri. Badan Standardisasi Nasional. 